\title{
The Synergy of Ecosystems of Blue and Green Infrastructure and Its Services in the Metropolitan Area-Chances and Dangers
}

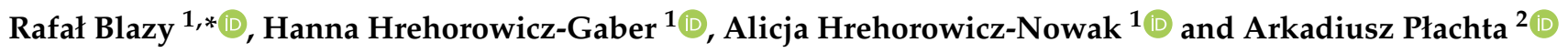 \\ 1 Department of Spatial Planning, Urban and Rural Design, Faculty of Architecture, Cracow University of \\ Technology, 31-155 Kraków, Poland; hanna.hrehorowicz-gaber@pk.edu.pl (H.H.-G.); h.alicja@o2.pl (A.H.-N.) \\ 2 Department of Climatology, Institute of Geography and Spatial Management, Jagiellonian University, \\ 30-387 Kraków, Poland; arkadiusz.plachta@doctoral.uj.edu.pl \\ * Correspondence: rblazy@pk.edu.pl
}

check for updates

Citation: Blazy, R.;

Hrehorowicz-Gaber, H.;

Hrehorowicz-Nowak, A.; Płachta, A.

The Synergy of Ecosystems of Blue

and Green Infrastructure and Its

Services in the Metropolitan

Area-Chances and Dangers.

Sustainability 2021, 13, 2103.

https://doi.org/10.3390/su13042103

Academic Editor: Shervin Hashemi

Received: 7 January 2021

Accepted: 11 February 2021

Published: 16 February 2021

Publisher's Note: MDPI stays neutral with regard to jurisdictional claims in published maps and institutional affiliations.

Copyright: (c) 2021 by the authors. Licensee MDPI, Basel, Switzerland. This article is an open access article distributed under the terms and conditions of the Creative Commons Attribution (CC BY) license (https:// creativecommons.org/licenses/by/ $4.0 /)$.

\begin{abstract}
Ecosystems have become synanthropized, and the degree of their transformation depends on their susceptibility to anthropopressure, but they are necessary for the functioning of the anthropogenic environment. They provide many ecosystem services, yet they are often not protected in any way, and their value is not taken into account at all in the process of creating local development plans. The analysis of the blue and green infrastructure covered three municipalities: Łapanów, Gdów, and Dobczyce. To calculate the benefits of ecosystem services, the method of calculating the Ve coefficient was adopted, which would enable a more accurate financial evaluation of the local development plan and make the previously synthetic economic coefficient of net present value (NPV) real. Besides, the impact of water bodies on the financial benefits of ecosystem services was analyzed. Only the protection of ecosystems introduced by including it in the local development plan enables full ecosystem synergy. Next to anthropological ecosystems, there are also natural ecosystems, which are necessary for the proper functioning of the commune. The network of those includes green (in the case of vegetated areas) and blue (in the case of surface waters) infrastructure, and their synergy is the key to the sustainable development of the commune.
\end{abstract}

Keywords: blue infrastructure; spatial planning; urban planning; ecosystem services

\section{Introduction}

A modern city in the conditions of Atlantic-European culture is usually a product of the planning process. Therefore, when considering the problem of synergism in the perspective of urban issues, one should, first of all, refer to the relationship between the structure of the environment and planning, especially in such unique ecosystems [1] as the Carpathians. In this regard, the structural plan should perform the function of aligning individual functional components of the city, determining the mutual relations of elements, and setting the directions of their development and the principles of cooperation between individual units, areas, and strategic points. In this case, for cities with a significant cultural and environmental potential [2], systemic solutions allowing for the cohesion of elements of structures created by humans with green and blue infrastructure are important. Preventing fragmentation and isolation of individual elements seems to be crucial. From the point of view of synergy, the greatest integration should take place in key places where all elements are layered and where additive integration should be sought at all levels of spatial and functional connections.

\subsection{Synergy as a Word Concept for Urban Ecosystems}

Synergy is a special form of coexistence and interdependence, characterized by the openness of individual elements and the exchange between them. This openness should be 
primarily functional [3] but also spatial of composed forms, elements, or urban assumptions. Absence of unnecessary barriers and spatial boundaries between individual objects of the created structure characterizes the easy accessibility of individual functions.

Thinking about synergy, we focus on acceleration and activation synergy, in which dynamic actions play an important role, about constitutive and harmonizing combat. Cooperation on a given team increases the level of its performance. The concept of synergy is often encountered in various revitalization programs, where it is treated as the socalled "Multiplier effect" [4] or "leverage effect" [5]. Sometimes we have the "apollo syndrome" [6], which is an effect of negative synergy in which one of the elements, due to its position or a joint attempt, subordinates other elements of the system.

In Polish cities, despite the efforts of urban planners, the investment pressure disrupts the synergy by dominating the other elements, including the natural environment. The most appropriate seems to be the synergy of equivalent components or micro components, i.e., insignificant, minor, and average elements. Additive synergism occurs when an effect results from the summation of the actions of individual ingredients. We can also talk about hyperadditional synergism [7] when there is a significant intensification of the interaction of components. It is worth transferring these general principles of synergism and considering each with individual adjacent functions and urban spaces. However, it is difficult to assess the degree of influence or intensification of the action of one element on the other. Taking into account the common urban planning theories and a certain canon of planning rules, activities of a synergistic nature should include joining (also in the sense of preventing fragmentation), coordination, activities leading to an increase in the effectiveness of individual elements (environment, human, and structure), and the aforementioned integration leading to the complementarity of the selected structure.

\subsection{Ecosystems and Their Importance for Urban Areas}

Urbanization is progressing and expanding around the world, but human survival depends on nature. Cities and their prosperity depend on the surrounding ecosystems, but they are also based on the ecosystems in the city itself. The definition of blue-green infrastructure includes a network of natural and semi-natural solutions with multiple functions. It takes into account many forms of retention, including ponds, basins, depressions of the land, reservoirs, and rain gardens. On the one hand this serves the purpose of rainwater management, on the other it serves purification, green and wetland areas, and other ecosystem services. These are the services provided by the environment for human use and which we can distinguish and define economically. Bolund and Hunhammar [8] identify seven different urban ecosystems in their research: street trees, lawns and parks, urban forests, farmland, wetlands, lakes/sea, and streams, and they identify six ecosystem services that are relevant and interact locally and directly to Stockholm and its population. Among these services, they list air filtration, microclimate, noise reduction, rainwater drainage, wastewater treatment, and recreational and cultural values.

The essence and importance of internal ecosystems in the city were discussed in the strategic documents of the European Union, which indicates the need to implement green-blue infrastructure to improve the continuity of green structures and rainwater management due to economic, social, and environmental benefits. In May 2016, the Urban Agenda for the EU was created with the Amsterdam Pact. The EU Urban Agenda approaches policy and legislation in EU cities in an integrated and coordinated way. It aims to boost economic growth, make life more attractive, and innovate European cities. It also deals with the effective identification and solving of social problems in their area. The EU Urban Agenda is an important framework in preventing urban fragmentation and urban sprawl. It is a tool for achieving the goals of sustainable development [9].

Internal relations between elements of the urban structure and ecologically active areas should lead to harmony and synergy, i.e., understanding and cooperation on a given level, which in the case of individual entities may take place through interdependence, 
which in this case is not a negative feature. Schematically, the stratification of the individual components of the synergistic structure of the city is presented in the figure below.

\section{Materials and Methods}

The strongest changes in phytocoenosis and zoocenosis and their interrelationships are observed in anthropogenic urban ecosystems [10]. It seems particularly important to maintain correct interconnections in areas of natural value, such as the Carpathians, where the environment is a value of a transboundary nature. There are 200 municipalities in the Polish Carpathians, including about 10 cities and over 50 towns. Many of them, especially those in the area of influence of larger cities, are subject to structural transformations, most often at the expense of green areas, waters, and forests (i.e., open areas). For research purposes, three locations in the Carpathian foothills in the area of influence of a large city of Krakow-Gdów, Dobczyce, and Łapanów (Figure 1)—were compiled. These three sites were also selected because of the connecting feature in an ecological aspect: they are the catchment areas of the Raba River. This is important since the river basin can be a reference field for mapping ecosystem services. Sub-catchments are one of the seven basic reference fields according to R.U. Syrbe and U. Walz (2012) [11] which are

- $\quad$ single patches, spatial landscape elements;

- "least common geometric unit" is generated automatically in GIS by superimposing maps of different components;

- administrative units;

- sub-catchments of rivers (or higher-order);

- natural units (soil, vegetation, etc.);

- landscape units;

- regular artificial geometric units (e.g., raster mesh).

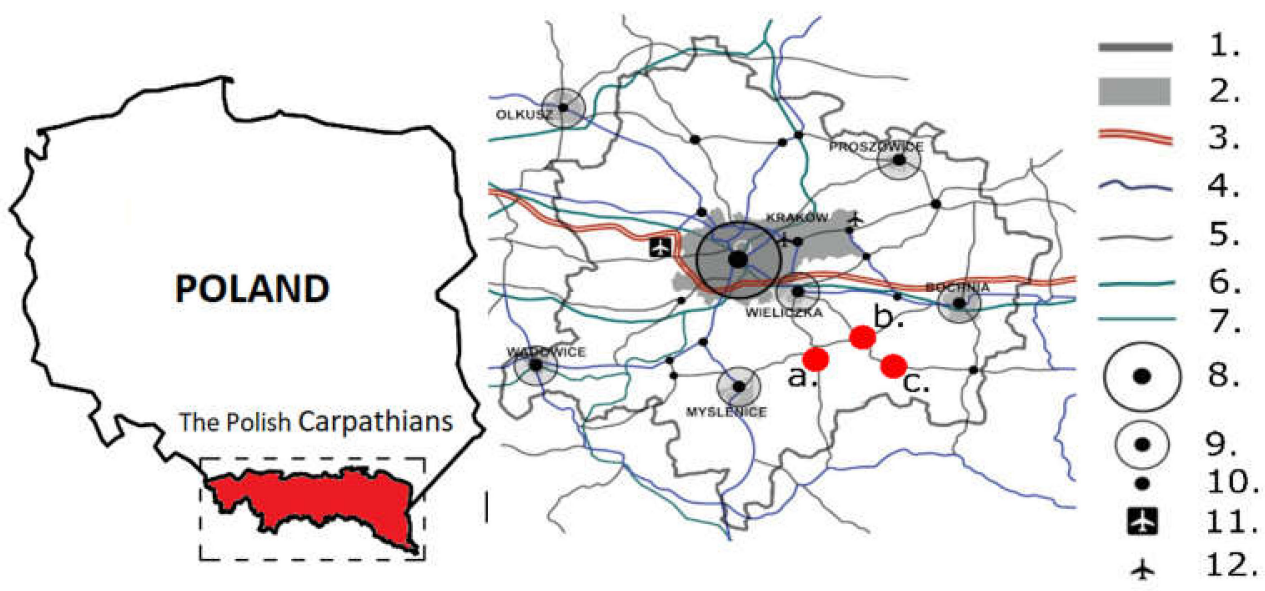

Figure 1. Locations considered in the study. a. Dobczyce; b. Gdów; c. Łapanów; 1. border of the Krakow metropolitan area; 2 . the main urban centers; 3 . highway; 4 . national and provincial roads; 5 . railway lines of national importance; 6. and 7. railway lines of regional importance; 8 . a transportation hub of national importance; 9. a transportation hub of regional importance; 10. a transportation hub of local importance; 11. passenger airports; 12. sport airports. Source: www.Dobczyce.pl/planowanieprzestrzenne (accessed on 27 January 2021).

The study was made based on acts of local law MPZP (Local Spatial Development Plan) and municipal data regarding financial forecasts for the presentation of the Local Spatial Development Plan. The forecast of financial effects [12-14] did not take into account the revenues from ecosystem services; therefore, the thesis was put forward that the neglected financial revenues from ecosystem services should be included in the process of creating the financial forecast [15]. 


\subsection{Ecosystem Services and Their Importance in Terms of Blue Infrastructure}

The basis for economic water management, capture, and not quick discharge-as is the case in urbanized and urbanizing areas-which transfers the effects of floods and inundations to the areas below. The blue infrastructure aims to improve local retention by managing the rainwater where it is produced, in the area where rainfall has occurred, supporting the traditional drainage system, e.g., in the event of sudden rainfall.

Gray infrastructure should complement the blue-green infrastructure and include hydro-technical infrastructure aimed at collecting and draining water, consisting of a sewage system that collects water from roads, squares and buildings, storm collectors, and a sewage treatment system. Dobczyckie Lake (Figure 2) is a dam reservoir, located about $30 \mathrm{~km}$ from Krakow and in the town of Dobczyce, a town with a population of several thousand, in the Małopolskie Voivodeship, in the area affected by the Kraków agglomeration. The reservoir was created in 1986 by damming the Raba's waters with a $30 \mathrm{~m}$ high and $617 \mathrm{~m}$ long dam. The reservoir has an area of approx. $10.7 \mathrm{~km}^{2}$ and a total capacity of 127 million $\mathrm{m}^{3}$.

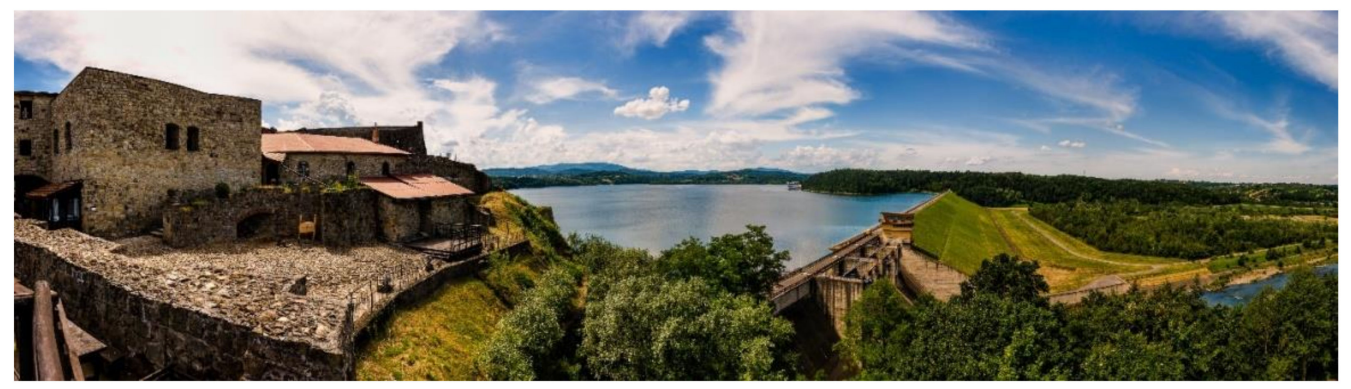

Figure 2. A view of the Dobczyce Lake. Source: author Krzysztof Cabak.

The green ecosystem and the water environment perform social and health functions. Outdoor recreation places are created or made more attractive, and health conditions are improved. Even a small number of plants can produce a relatively large amount of oxygen [16,17]: $155 \mathrm{~m}^{2}$ of green area produces enough oxygen for a person's daily oxygen demand. Greenery absorbs $\mathrm{CO} 2$ and dust, even as it cleans the air of harmful chemicals. The advantages of this are especially noticeable in cities on hot days because they experience the so-called "Islands of Heat" [18]. The more urbanized the structure with a smaller percentage of the biologically active area, the clearer the effects. They are created by replacing natural green areas with buildings, pavements, and concrete surfaces that absorb and retain heat. The local temperature drops by $2-3^{\circ} \mathrm{C}$ in the place of green or water areas.

Greenery and water in the city are also natural, landscape, and spatial functions. Benefits for nature include increasing biodiversity through plant development and creating habitat conditions for insects and other species of small animals, including insects and amphibians, as well as water management in containers, ponds, and basins. Caring for spatial values must be reflected in planning records. They must contain prejudices concerning both the shaping of the structure of buildings and the development of building plots and open areas. What is important for the Carpathian landscape is the multifaceted synergy of the internal elements of the urban structure with the surrounding Carpathian landscape.

Greenery in the city plays an important decorative role; ponds and basins with wetlands store and purify water from urban pollution, as well as improve the aesthetics of the local landscape. Green roofs that capture rainwater in the limited space of the city can act as corridors necessary to ensure landscape continuity; they can also have an aesthetic function because they are a distinct green decorative element that can be used to mask unattractive places. The green and blue infrastructure are fully correlated with activities for the development of tourism in the Raba Valley. Investments implemented in the Dobczyce Commune as part of the Raba Open River project (Figure 3) will serve to improve the 
tourist infrastructure along the Raba River by eliminating the existing barriers to transport infrastructure and increasing the accessibility of the river embankment for tourists. The preparation of a diverse offer of tourist products will extend the stay of tourists.

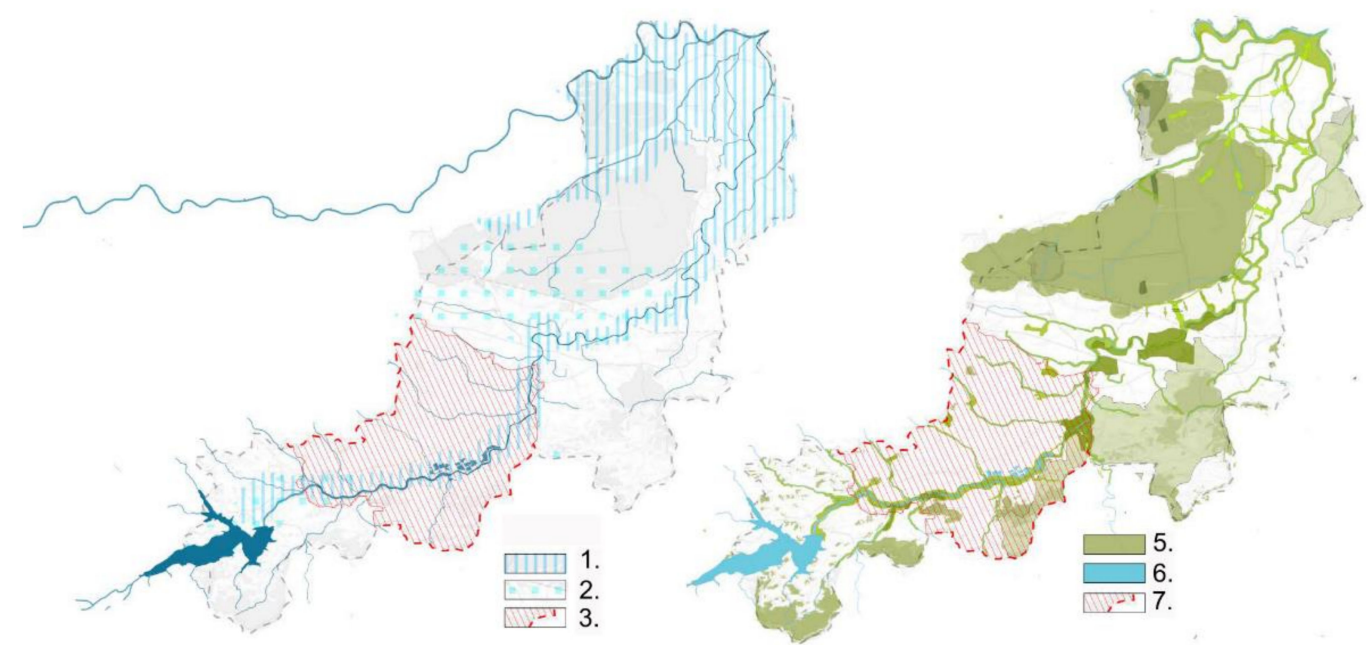

Figure 3. Schema of the green and blue infrastructure in the upper reaches of the Raba River. 1., 2.-blue infrastructure; 3., 7.-zone of influence of recreational ecosystem services, 5.- green infrastructure, 6.-blue infrastructure. Source: authors' materials.

Monetary valuation of ecosystem services assumes the determination of Total Economic Value [19], but in reality, it is only a fraction of the total valued environmental resource, including the ecosystem, because we are imperfectly able to inventory resources and assess non-market utility. A 2013 survey of European citizens revealed how people value ecosystem services that serve humanity. With a choice between different services, Europeans have found that maintaining biodiversity is a priority they are willing to pay for. The issue of ES valuation is of interest to various research disciplines: natural, economic, and social. The concept of environmental services appeared in 1981 [20], but already in the 1970s attempts were made to evaluate the so-called "Non-productive functions" [21]. In scientific literature, the valuation of ecosystem services has been discussed for many years [22-24]. The comparison of the valuation of ecosystems, including ecosystem services, can be carried out using several selected environmental valuation methods, such as conditional valuation [25], by defining Willingness to Pay (WTP), Willingness to Accept (WTA), hedonic pricing, travel cost, and cost methods.

In the case study, the valuation of the entire green-blue infrastructure of the urban ecosystem as a whole was estimated since ecosystems provide many services simultaneously (Table 1), the "availability of which depends on the functioning of the ecosystem as a whole, consisting of many mutually synergistic elements" [26,27].

Table 1. Levels and measures of biodiversity reduced by Feledyn-Szewczyk B., Sienkiewicz 2010.

\begin{tabular}{ccc}
\hline Bio-Diversity & Quantity & Quality \\
\hline ecosystem brand & $\begin{array}{c}\text { range and range of species } \\
\text { of communities } \\
\text { species richness }\end{array}$ & $\begin{array}{c}\text { The variety of ecosystems } \\
\text { and communities }\end{array}$ \\
genetic brand & mutations & $\begin{array}{c}\text { Species differentiation, equality } \\
\text { Allele variability in the gene pool and } \\
\text { gene exchange }\end{array}$ \\
\hline
\end{tabular}

The problem of biodiversity loss was noticed relatively long ago; in 1992, during the Convention on Biological Diversity signed in Rio de Janeiro [28], the necessity to reduce the loss of biodiversity by 2010 was recorded. This goal was not met back then, so similar 
actions were taken at the Rio +20 Conference in 2012, which resulted in the creation of the EU Biodiversity Strategy 2020 [29].

Protection of water reservoirs should be an indispensable planning document (spatial planning structure in Poland is shown in Figure 4), while these provisions have a real and significant impact on the condition of water reservoirs, which in turn also translates into the provision of ecosystem services by them. The introduction of provisions for the protection of water bodies into spatial planning directly impacts the quality of life of their environment. The current hierarchical spatial planning layout is shown in the chart below. It is similar to the planning systems in the entire Carpathians.

\section{SPATIAL PLANNING DOCUMENTS IN POLAND}

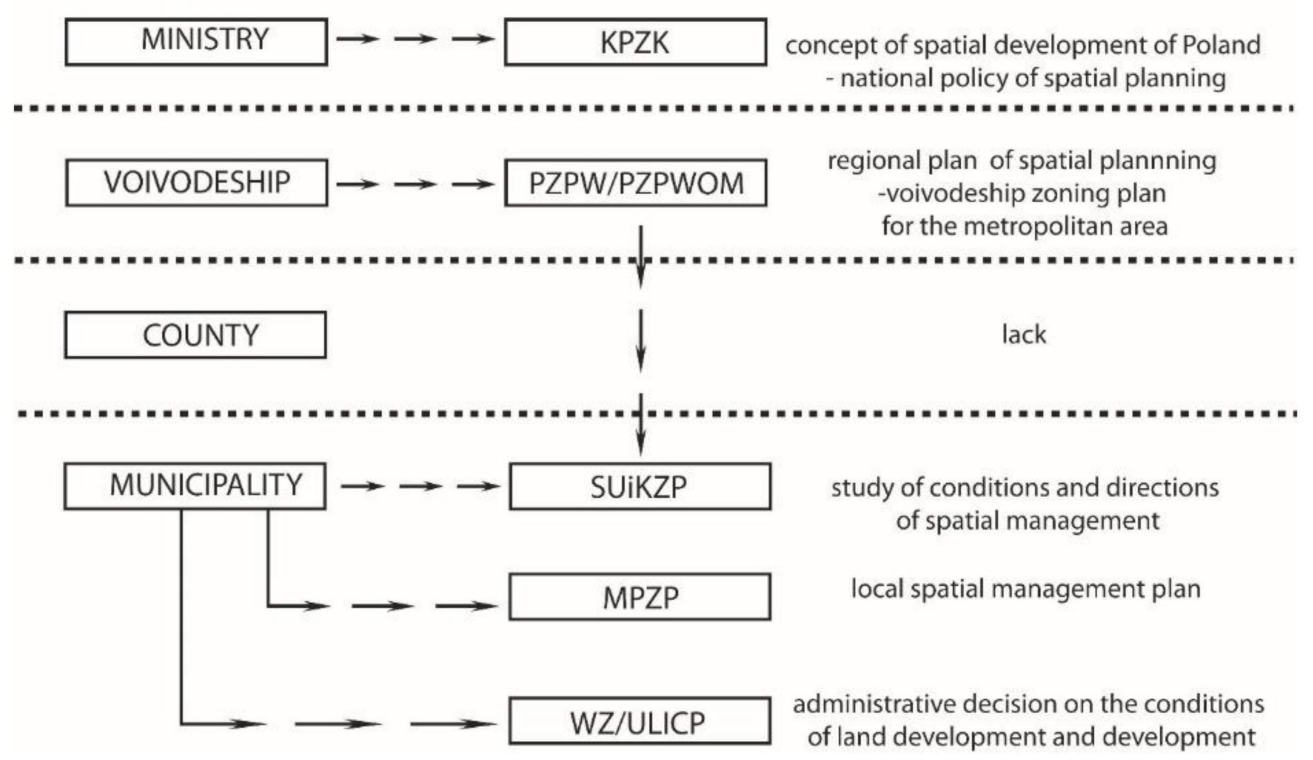

Figure 4. The spatial planning system in force in Poland. Source: authors' study.

Due to the scale, it is only the commune level that makes it possible to define real rules for shaping the space. The directional document of communes in the study of the conditions and directions of spatial development (SUiKZP) is the basic document creating general spatial policy and local rules of municipal development. In the study prepared on a scale of 1:10,000 (with possible exceptions), the commune authorities determine the basic scope of spatial policy and indicate areas intended for development, the initial location of technical infrastructure, scenic and landscape protection, as well as protected areas in terms of natural and cultural resources. The study also designates areas for various reasons excluded from the possibility of their development and areas for which local spatial development plans should be prepared. In their absence, the basis for spatial management is administrative decisions on development conditions, which do not have to comply with SUIKZP arrangements and results in the lack of protection of space and the environment. As a result, in areas not covered by the local spatial development plan, it is possible to implement investments contrary to the assumptions of the local policy and the spatial structure of the commune. Local spatial development plans are the direct basis for issuing building permits. The arrangements of the local development plan define the conditions of development and regulate the way of developing specific properties located in the area covered by the plan, which is to ensure transparency and stability of the policy of local authorities and to preserve the spatial order.

The Act of 27 March 2003, on spatial planning and development introduced the obligation to prepare an environmental impact assessment plan and financial impact forecast as an appendix to the spatial development plan. The scope of the forecasts is defined in the Regulation of the Council of Ministers of 26 August 2003, on the required 
scope of the local spatial development plan project. The forecast of the impact of the plan's findings on the environment includes guidelines for shaping green-blue infrastructure to prevent its fragmentation, forms of nature protection, and other elements significant for the environment.

Ecosystem services are mainly public goods that are not a market product; they do not have a price and, as such, become worthless for the inhabitants. The lack of valuation is a major cause of ecosystem degradation and loss of biodiversity. If we want to guide our ecological safety, we must "measure" ecosystems and biodiversity and record it in local planning documents. Most of the services are classified as indirect benefits resulting from various natural processes, the effects of which are often delayed in time and the resulting changes are non-linear $[30,31]$. The table below (Table 2 ) shows the commonly used methods of ecosystem services valuation.

Table 2. Methods of ecosystem valuation.

\begin{tabular}{|c|c|c|c|c|}
\hline Assessment Method & $\begin{array}{c}\text { Assessed Ecosystem } \\
\text { Services }\end{array}$ & $\begin{array}{c}\text { Advantages of the } \\
\text { Method }\end{array}$ & Method Limitations & Comments \\
\hline Market prices & $\begin{array}{l}\text { Only valid for } \\
\text { the market }\end{array}$ & $\begin{array}{l}\text { Market data readily } \\
\text { available and reliable }\end{array}$ & $\begin{array}{l}\text { Limited to } \\
\text { market-related services }\end{array}$ & $\begin{array}{l}\text { They set the lower limit } \\
\text { of values, do not } \\
\text { include subsidies, do } \\
\text { not take into account } \\
\text { useless values }\end{array}$ \\
\hline Replacement costs & $\begin{array}{l}\text { They depend on the } \\
\text { existence of the real } \\
\text { estate market } \\
\text { placeholders }\end{array}$ & $\begin{array}{l}\text { Market data readily } \\
\text { available and reliable }\end{array}$ & $\begin{array}{l}\text { It is possible to } \\
\text { overestimate the value }\end{array}$ & $\begin{array}{c}\text { For example, the costs } \\
\text { of building flood } \\
\text { embankments }\end{array}$ \\
\hline $\begin{array}{c}\text { Costs of } \\
\text { hedonistic behavior }\end{array}$ & $\begin{array}{l}\text { Services that affect air } \\
\text { quality and } \\
\text { visual-aesthetic values }\end{array}$ & $\begin{array}{l}\text { Market data readily } \\
\text { available and reliable }\end{array}$ & $\begin{array}{l}\text { A huge amount of data } \\
\text { is required, often } \\
\text { missing and limited to } \\
\text { land ownership }\end{array}$ & $\begin{array}{l}\text { The price of the } \\
\text { property is influenced } \\
\text { by the natural features } \\
\text { of the place, its quality, } \\
\text { and environmental } \\
\text { hazards }\end{array}$ \\
\hline Travel costs & $\begin{array}{l}\text { Services that affect the } \\
\text { recreational value of } \\
\text { a place }\end{array}$ & $\begin{array}{l}\text { It is based on } \\
\text { observations } \\
\text { and surveys }\end{array}$ & $\begin{array}{l}\text { It is just for recreational } \\
\text { benefits. Trips with } \\
\text { multiple destinations } \\
\text { and destinations are } \\
\text { not included. }\end{array}$ & $\begin{array}{l}\text { The cost incurred by a } \\
\text { tourist to arrive at a } \\
\text { given place (travel, } \\
\text { overnight) is a measure } \\
\text { of the } \\
\text { recreational value. }\end{array}$ \\
\hline
\end{tabular}

Ecosystem services can only be valued in scope, and possibly never fully valued. Economic quantification may only be possible for that part of the services that are relatively well understood and for which there are sufficient data. The economic valuation of ES is difficult and error-prone.

An example of calculations for the preparation of a forecast of financial effects with ecosystem services of Dobczyce Lake is presented below. The data were ranked down by the FEGS Ecosystem Ranking System, Final Ecosystem Goods and Services Classification System (FEGS-CS) [32], followed by a specific type of ecosystem providing calculation of potential, resource, and supply numerical indicators. The calculations of the indicators do not uniquely calculate the scheme for each ecosystem, and their calculation depends on the nature of the ecosystem for the user of the year. The analysis of the results was based on the method of calculating the evaluation and valuation indicators developed by Piotr Mikołajczyk from the Environment Information Center UNEP/GRID-Warsaw [33].

In the case of procurement and cultural services, the calculation of the real benefits is easier due to the possibility of using the already collected data [34]. Nevertheless, regulatory benefits to define and convert are also possible. The Dobczyce Lake, if necessary, regulates water circulation [35,36] and, as a result, changes in insolation. In his research, Matuszko (2005) cites data showing an increase in the number of sunny days a year. 
"The average annual sunshine duration before the creation of the reservoir (1971-1980) is 1451 hours, and after its formation (1991-2000) it increased and amounts to 1544 hours." In a whole year, cultivation is more efficient and economical; the number of hours of light in greenhouse increases and crops and this is affecting directly on the cost of products (and has an impact on the lives of the city's inhabitants).

The table below (Table 3) shows that the lake, as an ecosystem structure, provides services that bring measurable financial benefits and which should be included in the forecast of financial consequences for the commune.

Table 3. Sample conversion of ecosystem services into financial benefits calculated for Dobczyce based on data from the Commune Office.

\begin{tabular}{|c|c|c|c|c|c|c|}
\hline $\begin{array}{l}\text { Service } \\
\text { According to } \\
\text { FEGS }\end{array}$ & $\begin{array}{l}\text { Description of } \\
\text { the Benefit }\end{array}$ & $\begin{array}{l}\text { Type of } \\
\text { Ecosystem } \\
\text { Providing the } \\
\text { Service }\end{array}$ & $\begin{array}{c}\text { Potential } \\
\text { Indicators }\end{array}$ & $\begin{array}{l}\text { Pool/Resource } \\
\text { Indicators }\end{array}$ & $\begin{array}{c}\text { Supply } \\
\text { Indicators }\end{array}$ & $\begin{array}{c}\text { Assessment } \\
\text { Possible Based } \\
\text { on Existing } \\
\text { Data }\end{array}$ \\
\hline 00.0601 & $\begin{array}{l}\text { Cultural: } \\
\text { Tourist site }\end{array}$ & Lagoon & $25.27 €^{2}$ & $\begin{array}{c}107,589 \\
\text { (number of } \\
\text { accomodations }^{1} \text { ) }\end{array}$ & $27,187.74 €$ & $\begin{array}{l}\text { Low error } \\
\text { threshold }\end{array}$ \\
\hline 00.0801 & $\begin{array}{l}\text { Cultural: } \\
\text { Educational } \\
\text { cruise on the } \\
\text { reservoir }\end{array}$ & Lagoon & $32.97 €^{4}$ & 28,800 persons $^{3}$ & $949,536.00 €$ & $\begin{array}{l}\text { Low error } \\
\text { threshold }\end{array}$ \\
\hline 00.0205 & $\begin{array}{l}\text { Supply: } \\
\text { Electricity } \\
\text { production }\end{array}$ & Lagoon & $0.12 €^{5}$ & $9.6 \mathrm{GWh}^{6}$ & $1,160,401.44 €$ & $\begin{array}{l}\text { Low error } \\
\text { threshold }\end{array}$ \\
\hline 31 & $\begin{array}{l}\text { Regulating: } \\
\text { Influence on } \\
\text { water } \\
\text { circulation and } \\
\text { insolation }\end{array}$ & Lagoon & $0.12 €^{5}$ & $11 \mathrm{kWh}^{7}$ & $(+224.83 €)^{8}$ & $\begin{array}{l}\text { Low error } \\
\text { threshold }\end{array}$ \\
\hline
\end{tabular}

${ }^{1}$ Data averaged based on the number of offers sold in the city in the commune's strategy for 2016-2022. ${ }^{2}$ Average price of a night in the city. ${ }^{3}$ Number of people flowing into the city related to services. The data for 2019 show that 4800 used the weekend cruises within 2 months. ${ }^{4}$ Cost of communication both ways, the price of accommodation and meals. ${ }^{5}$ Average price (Tauron data) for households per $1 \mathrm{kWh} .{ }^{6}$ Annual electricity production at the hydroelectric power plant in Dobczyce. ${ }^{7}$ The amount of $\mathrm{kWh}$ is equivalent to the time of receiving solar irradiation within 1 hour for a greenhouse with 100 lamps. ${ }^{8}$ Cost saved after the tank-The product of the hourly difference in insolation before and after connecting the tanks $(93 \mathrm{~h})$ and the cost of electricity consumption.

However, the forecast of financial effects does not refer to the valuation of ecosystem services that the environment provides to man, and thanks to the method of valuation of these services, a clear economic effect can be indicated. Including the indicator of ecosystem services in the forecast of financial effects could effectively protect the environmental value enshrined in local law, which is green and blue infrastructure. In such a case, the local spatial development plan would become a real (legally valid) protection tool.

\subsection{The Method of Analysis in the Aspect of Environmental Value-Obtaining and Compiling Municipality Data}

Considering the values in Section 2 in favor of the significant role of green and blue infrastructure and its benefits (including financial), it seems reasonable to include the issue of ecosystem services in the planning process, and in particular when creating a forecast of financial consequences. The net present value method (NPV method for short) is commonly used in creating financial forecasts, belongs to the category of dynamic methods, and is based on the discounted cash flow analysis at a given discount rate [37]. $N P V^{n}{ }_{t=1}=\frac{\Sigma C F_{t}}{(1+r)^{t}}-C F^{0}$, where NPV is net present value; $C F_{t}$ is free cash flows for each year of the plan, as the difference between effects and costs; costs (outlays) related to the transformation of the area in year 0 (before the plan enters into force); $r$ is discount rate $0.13 \%$ (in Poland on 27 January 2021) [38] (as a decimal); $t$ is duration of the plan (10 years in this case); $\frac{1}{(1+r)^{t}}$ is discounting factor. 
To be able to determine the forecast of financial effects with the NPV method and to enrich it with the coefficient resulting from the benefits of ecosystem services, the table below (Table 4) lists the data necessary to convert the net present value.

Table 4. Communal data necessary to prepare a forecast of the financial effects of local development plan.

\begin{tabular}{|c|c|c|c|}
\hline Wartość & Łapanów & Gdów & Dobczyce \\
\hline $\begin{array}{l}\text { Price }{ }^{1} \text { per } 1 \mathrm{~m}^{2} \text { of a plot of land } \\
\text { or land in a commune in the } \\
\text { Małopolskie Voivodeship }\end{array}$ & $8.57 € / \mathrm{m}^{2}$ & $12.74 € / \mathrm{m}^{2}$ & $16.70 € / \mathrm{m}^{2}$ \\
\hline $\begin{array}{l}\text { Change in prices of plots of land } \\
\text { or land in the commune in the } \\
\text { Małopolskie Voivodeship in the } \\
\text { last } 12 \text { months }\end{array}$ & $11 \%$ & $-8 \%$ & $124 \%$ \\
\hline $\begin{array}{c}\text { Average plot or land value }{ }^{1} \text { in a } \\
\text { commune in the Małopolskie } \\
\text { Voivodeship }\end{array}$ & $23,020.34 €$ & $41,129.32 €$ & $71,232.25 €$ \\
\hline $\begin{array}{l}\text { Number of plots } \\
\text { or land for sale in the commune } \\
\text { in the Małopolskie Voivodeship }\end{array}$ & 62 & 64 & 10 \\
\hline $\begin{array}{l}\text { in the Małopolskie Voivodeship } \\
\text { Average area plot } \\
\text { or land in the commune in the } \\
\text { Lesser Poland Voivodeship }\end{array}$ & $2942 \mathrm{~m}^{2}$ & $3703 \mathrm{~m}^{2}$ & $5189 \mathrm{~m}^{2}$ \\
\hline $\begin{array}{l}\text { Average price }{ }^{1} \text { of an agricultural } \\
\text { plot per } 1 \mathrm{ar}\end{array}$ & $3.95 €$ & $3.29 €$ & $8.79 €$ \\
\hline $\begin{array}{l}\text { Average house } \\
\text { value }^{1}\end{array}$ & $109,847.45 €$ & $109,847.45 €$ & $118,635.25 €$ \\
\hline \multicolumn{4}{|c|}{ Value calculated based on the exchange rate on $27 / 01 / 2020$ ( 1 PLN $=0.219773$ EUR). } \\
\hline $\begin{array}{l}\text { The calculation of the forec } \\
\text { lan which is converted from } \\
\text { coefficient enriching the previor } \\
\mathrm{t} \text { is necessary to measure ecosy } \\
\text { Table } 5 \text {. }\end{array}$ & $\begin{array}{l}\text { inancial imp } \\
\text { ultural to by }\end{array}$ & $\begin{array}{l}\text { the plan is } b \\
g \text { areas. Mor } \\
\text { al benefits fr } \\
\text { son, the nece }\end{array}$ & $\begin{array}{l}\text { n the area o } \\
\text { to calculate } \\
\text { system serv } \\
\text { reas are liste }\end{array}$ \\
\hline
\end{tabular}

Table 5. Levels and measures of biodiversity reduced by Feledyn-Szewczyk B., Sienkiewicz 2010.

\begin{tabular}{cccc}
\hline & Lapanów & Gdów & Dobczyce \\
\hline $\begin{array}{c}\text { MPZP/act } \\
\text { of a local law change }\end{array}$ & $\begin{array}{c}\text { Resolution amending: Local } \\
\text { Plan No. } \\
\text { XIX/140/2012-3.49 } \mathrm{km}^{21}\end{array}$ & $\begin{array}{c}\text { Resolution No. } \\
\text { XXXVI/249/2017 of the Gdów } \\
\text { Commune Council of 8 June } \\
2017-1.013 \mathrm{~km}^{2}\end{array}$ & $\begin{array}{c}\text { Resolution No. XXVI/164/16 } \\
\text { of the City Council of } \\
\text { Dobczyce } \\
-12.940 \mathrm{~km}^{2}\end{array}$ \\
\hline $\begin{array}{c}\text { Agricultural } \\
\text { plots }\end{array}$ & $35 \mathrm{ha}$ & $12.10 \mathrm{ha}$ & $502.08 \mathrm{ha}$ \\
$\begin{array}{c}\text { building plots } \\
\text { Water ecosystem blue } \\
\text { infrastructure }\end{array}$ & $69.64 \mathrm{ha}$ & $165.01 \mathrm{ha}$ & $233.73 \mathrm{ha}$ \\
Alluvial green infrastructure & $3.5 \mathrm{ha}$ & $16.55 \mathrm{ha}$ & $140.00 \mathrm{ha}$ \\
recreation green infrastructure & $68.76 \mathrm{ha}$ & $19.11 \mathrm{ha}$ & $65.54 \mathrm{ha}$ \\
forest green infrastructure & $5 \mathrm{ha}$ & $53.73 \mathrm{ha}$ & $18.45 \mathrm{ha}$ \\
\hline
\end{tabular}

${ }^{1}$ Area of the fragment in the vicinity of the reservoir to which we refer (because the local development plan was prepared for the entire commune).

In the analysis of ecosystem services, it is important to pay attention to the surface of the water ecosystem in Dobczyce. Lake Dobczyckie is the third largest lake in the Małopolskie Voivodeship, and its condition is improving compared to previous years. Therefore, it should be suspected that after updating the NPV formula and extending it with the ecosystem services factor, its value will increase significantly concerning Gdów 
(no large ecosystem areas) and Łapanów (much smaller water ecosystem). Table 6 presents artificially created water reservoirs in Małopolska. The reservoirs have been classified in terms of their general condition based on data on the status of waters in the Małopolskie Voivodeship obtained from the website of the Regional Water Management Authority in Kraków. The condition and tendency of changes in the condition of the water reservoir were determined by placing the sign " $\downarrow$ " next to them when the condition of the reservoir is in degradation, the sign " = " when the condition of the reservoir does not change, and the sign " $\uparrow$ " when the condition of the reservoir improves. Then, the types of protection that the tanks are subject to have been defined. SUIKZP (study of conditions and directions of spatial management) and MPZP documents were analyzed for the areas where the reservoirs are located (to help the reader understand the topic, Figure 4 shows the spatial planning system in Poland), and checked whether provisions are protecting the reservoir or ecosystem services. The summary also includes other types of protection including water reservoirs, such as sanitary protection or ecological protection.

Table 6. Artificial reservoirs in Małopolska. Prepared based on summaries prepared by the Regional Water Management Authority in Kraków. https: / / krakow.wody.gov.pl/ data (accessed on 27 January 2021) for years 2008-2016.

\begin{tabular}{|c|c|c|c|c|c|c|c|c|}
\hline $\begin{array}{c}\text { Name of the } \\
\text { Water Reservoir }\end{array}$ & $\begin{array}{l}\text { Area } \\
\text { (ha) }\end{array}$ & $\begin{array}{l}\text { Max. Depth. } \\
\text { (m) }\end{array}$ & Impact $^{1}$ & Genesis & Text in MPZP ${ }^{2}$ & $\begin{array}{c}\text { Text in } \\
\text { SUIKZPP }^{2}\end{array}$ & Condition & $\begin{array}{c}\text { Ratio } \\
\text { Area }(\%)^{3}\end{array}$ \\
\hline Bagry (Kraków) & 31.4 & 10.0 & yes (Kraków) & $\begin{array}{l}\text { Post-industrial } \\
\text { excavation flooded } \\
\text { flooded }\end{array}$ & no protection & protection & $=$ & $1.3^{8}$ \\
\hline Balaton (Trzebinia) & 3.0 & 9.5 & yes & $\begin{array}{l}\text { quarry-drinking } \\
\text { water reservoir }\end{array}$ & no protection & protection & $\downarrow$ & 0.02 \\
\hline Chechelskie Lake & 54 & No data & no & A dam reservoir & no protection & protection & No data & 0.5 \\
\hline Czorsztyńskie Lake & 1100.0 & 50.0 & no & A dam reservoir & no protection & protection & $\downarrow$ & 0.05 \\
\hline Dąbski Pond & 2.54 & No data & yes (Kraków) & $\begin{array}{c}\text { Post-industrial } \\
\text { excavation flooded }\end{array}$ & ecological area & protection & $=$ & $1.3^{8}$ \\
\hline Dobczyckie Lake & 1065.0 & 28.0 & yes & A dam reservoir & no protection & protection & $\uparrow$ & $16.0^{7}$ \\
\hline $\begin{array}{l}\text { Gdow- } \\
\text { Nieznanowice }\end{array}$ & 16.55 & No data & yes & $\begin{array}{l}\text { Post-industrial } \\
\text { excavation flooded }\end{array}$ & Protection & protection & $=$ & No data \\
\hline Klimkowskie Lake & 310.0 & 25.0 & no & A dam reservoir & no protection & protection & $=$ & 1.0 \\
\hline Kryspinów Lagoon & 1500.0 & 8.0 & Yes $^{5}$ & No data & no protection & protection & $\uparrow$ & Not specified ${ }^{6}$ \\
\hline Łapanów Lagoon & 3.5 & No data & yes & A dam reservoir & no protection & protection & $\downarrow$ & No data \\
\hline Mucharskie Lake & 1035.0 & $50.0^{4}$ & no & A dam reservoir & no protection & protection & No data & 13.0 \\
\hline $\begin{array}{c}\text { Nowohucki } \\
\text { Lagoon }\end{array}$ & 7.0 & 2.5 & yes (Kraków) & $\begin{array}{l}\text { Recreational } \\
\text { reservoir }\end{array}$ & no protection & protection & $\downarrow$ & $1.3^{8}$ \\
\hline Płaszowski Pond & 7.9 & No data & yes (Kraków) & $\begin{array}{c}\text { Post-industrial } \\
\text { excavation flooded }\end{array}$ & no protection & protection & $=$ & $13.0^{8}$ \\
\hline $\begin{array}{l}\text { Przylasek Rusiecki } \\
\text { (lake reservoirs) }\end{array}$ & 0.0086 & No data & yes (Kraków) & $\begin{array}{c}\text { Natural oxbow of } \\
\text { the Vistula }\end{array}$ & no protection & protection & $\downarrow$ & $1.3^{8}$ \\
\hline Rożnowskie Lake & 1600.0 & 35.0 & no & A dam reservoir & Protection & protection & $\downarrow$ & 4.5 \\
\hline Zakrzówek Lagoon & 23.0 & 32.0 & yes (Kraków) & Flooded quarry & ecological area & protection & $\uparrow$ & $1.3^{8}$ \\
\hline Zesławicki Lagoon & No data & No data & yes $^{5}$ & $\begin{array}{l}\text { Post-industrial } \\
\text { excavation flooded }\end{array}$ & no protection & protection & $\downarrow$ & Not specified $^{6}$ \\
\hline
\end{tabular}

${ }^{1}$ In the impact of the Krakow agglomeration. ${ }^{2}$ Regarding reservoir or ecosystem services. ${ }^{3}$ Ratio of water to the area of the commune.

${ }^{4}$ Height of the dam. ${ }^{5}$ Partially in the city of Krakow. ${ }^{6}$ Not specified due to merger across multiple communes. ${ }^{7}$ The lake covers $82 \%$ of the area of the city of Dobczyce. ${ }^{8}$ Percentage of the area of the City of Krakow calculated in total for Krakow.

\section{Results}

Adoption of NPV method and ecosystem services factor

From the collected data for the local development plan of each commune the values of CFt and CF0 were calculated to apply the NPV method and then analyze the application of the ecosystem services ratio. Averaged price of an agricultural plot, the average price of an undeveloped building plot, and average prices of buildings (Table 7) were used for calculations. As a result of the above actions, the NPV economic coefficient was obtained. 
Table 7. Average prices of agricultural plots, undeveloped building plots, and buildings, based on municipals statistics. Values calculated based on the exchange rate on 27 January 2020 (1 PLN = 0.219773 EUR).

\begin{tabular}{lccc}
\hline & $\begin{array}{c}\text { The Average Price of } \\
\text { an Agricultural Plot } \\
{\left[\boldsymbol{\epsilon} \text { ] per } \mathbf{~ m}^{\mathbf{2}}\right.}\end{array}$ & $\begin{array}{c}\text { The Average Price of an } \\
\text { Undeveloped Building } \\
\text { Plot [€] Per } \mathbf{~ m}^{\mathbf{2}}\end{array}$ & The Price of Building [€] \\
\hline Łapanów & 3.95 & 8.57 & $109,906.20$ \\
Gdów & 3.29 & 12.74 & $109,906.20$ \\
Dobczyce & 8.79 & 16.70 & $118,698.70$ \\
\hline
\end{tabular}

To take into account the additional benefits of ecosystem services, the percentage share of ecosystem area (from Table 5) concerning the built-up area was calculated. As a result of the analysis, it was assumed that the benefit from ecosystem services will not exceed $1 \%$ of the obtained value. The coefficient of ecosystem services marked as $V_{e}$ is, therefore, a promil of the ratio of ecosystems area to building area.

$V_{e}=\frac{\Sigma e_{s} \times 100 \%}{\Sigma b_{s}} \times 1 \%$, where $V_{e}$ is the coefficient of ecosystem services, $e_{s}$ is ecosystem surfaces, and $b_{s}$ is areas intended for development (built-up areas).

The table below presents the NPV values for local development plans for municipalities. The values of $V_{e}$ are calculated from the data contained in Table 8, and NPVe is updated by the amount being the product of NPV and $V_{e}$ (see Table 9).

Table 8. NPF calculated for Łapanów, Gdów, and Dobczyce municipalities. Values calculated based on the exchange rate on 27/01/2020 (1 PLN = 0.219773 EUR).

\begin{tabular}{lccc}
\hline & $\mathbf{C F}_{\mathbf{t}}{ }^{\mathbf{1}}$ & $\mathbf{C F}_{\mathbf{0}}{ }^{\mathbf{2}}$ & $\mathbf{N P V}^{\mathbf{3}}$ \\
\hline Łapanów & $5,130,228,433.03 €$ & $277,056,043.31 €$ & $3,489,118,707.36 €$ \\
Gdów & $15,105,062,302.82 €$ & $543,828,778.80 €$ & $10,545,547,414.64 €$ \\
Dobczyce & $277,634,186,789.86 €$ & $2,056,663,606.55 €$ & $201,795,942,848.67 €$ \\
\hline
\end{tabular}

${ }^{1}$ Free cash flows for each year of the plan, as the difference between effects and costs. ${ }^{2}$ Costs (outlays) related to the transformation of the area in year 0 (before the plan enters into force) ${ }^{3}$ Net present value.

Table 9. $\mathrm{NPV}_{\mathrm{e}}$ updated with Ve coefficient NPV value calculated for Łapanów, Gdów, and Dobczyce municipalities. Values calculated based on the exchange rate on 27/01/2020 (1 PLN = 0.219773 EUR).

\begin{tabular}{lcccc}
\hline NPV & V & NPV & $\begin{array}{c}\text { Financial } \\
\text { Difference Taking } \\
\text { into Account the } \\
\text { Coefficient } \mathbf{V}_{\mathbf{e}}\end{array}$ \\
\hline Łapanów & $3,489,118,707.36 €$ & 0.19 & $4,152,051,261.76 €$ & $662,932,554.40 €$ \\
Gdów & $10,545,547,414.64 €$ & 0.03 & $10,861,913,837.08 €$ & $316,366,422.44 €$ \\
Dobczyce & $201,795,942,848.67 €$ & 0.32 & $266,370,644,560.24 €$ & $64,574,701,711.57 €$ \\
\hline
\end{tabular}

The table shows a directly proportional increase in monetary profits to the increase in the area of ecosystems. The presence of water reservoirs as ecosystems in Dobczyce and Łapanów is also clearly visible here.

\section{Discussion}

The implementation of solutions in the field of green and blue infrastructure in urban space requires a change in the approach of many professional environments to solving problems. Including ecosystem services in climate change adaptation plans gives hope for the implementation of systemic solutions supporting the development of legal, financial, and educational (including training) tools in the field of green and blue infrastructure. Its use in smaller cities located in agglomeration zones of large cities also increases the ability to adapt to changing climatic conditions. The subject of the valuation of ecosystem services was undertaken in 1997 by R. Constanza [39], who noted that "The issue of valuation is 
inseparable from the choices and decisions we have to make about ecological systems. Some argue that the valuation of ecosystems is either impossible or unwise, that we cannot place a value on such intangibles as human life, environmental aesthetics, or long-term ecological benefits. But, in fact, we do so every day." Constanza points that the search for choices entails the necessity of valuation. Accordingly, this also includes decisions regarding spatial development and ecosystems for valuation. The difference can only lie in the accuracy and whether the valuation of production with an understanding of the topic in the reduction of ecological knowledge. In the considerations of De Groot (2002), he shows that when assessing ecosystem services available, it is necessary to take into account their totality for a given area due to the synergy that should characterize the relationship between these services. "Since most functions and related ecosystem processes are inter-linked, sustainable use levels should be determined under complex system conditions".

To achieve the desired effect of "synergy" of ecosystems and to protect Green Urban Infrastructure together with the ecosystem services it provides, efficient and well-thought-out spatial planning is necessary. A tool that can significantly improve the level of protection of ecosystems is the inclusion of ecosystem services in the forecast of financial effects for local development plans based on NPV method [40]. Such action will not only allow for a more precise determination of the financial benefits resulting from the preservation of ecosystem areas but also, as a result, help protect these areas against excessive use for development.

In particular, forecasts of financial effects should include the following:

(1) a forecast of the impact of the local zoning plan on the commune's income and expenses, including real estate tax and other income related to the commune's real estate turnover as well as the fees and compensation referred to in Art. 36 of the act;

(2) a forecast of the impact of the provisions of the local spatial development plan on expenditure related to the implementation of investments in the field of technical infrastructure, which are part of the commune's tasks;

(3) conclusions and recommendations regarding the adoption of the proposed solutions to the draft local plan, resulting from taking into account their financial multiplier effects;

(4) financial impact of ecosystem services expressed by adding the value of $V_{e}$ to the economic factor NPV.

The first three elements listed above are included in most financial impact forecasts for the local spatial development plan performed in Polish municipalities. They do not yet include point 4 , which has an important protective function for ecosystems and their services and facilitates the translation of ecosystem services into measurable benefits. Such a procedure will also significantly improve the attitude of the local community to the protection and leaving of ecosystem areas in a condition that enables the continuity of service provision. Therefore, taking into account the factor of income from these services may become an important advantage during public consultations that take place when making local plans.

The research presented in the article may also refer to the smaller and larger scale of the problem (national, European, or the scale of a single local project) and constitute a universal tool for calculating and comparing the benefits of leaving ecosystems and protecting them. This will help to maintain a balance between the urbanized space and the area of green and blue infrastructure.

\section{Conclusions}

Documents of local law relating to spatial planning in the area of a commune or larger administrative unit are the basic tool for determining the directions of spatial development. Often, these documents do not take into account additional conditions for the presence of ecosystems, and ecosystem services, which are necessary for the appropriate synergy of anthropogenic and natural ecosystems, and also are a source of measurable, financial benefits. As a result, ecosystem services are not anticipated in spatial development or protected in any way. Similar proposals, e.g., the InVEST method of ecosystem services 
valuation, have already been made for more specialized areas such as marine areas, "Integrated Valuation of Ecosystem Services and Tradeoffs (InVEST) evaluates how alternative management or climate scenarios yield changes in the flow of ecosystem services. outputs are expressed in biophysical units (e.g., landed biomass) or socioeconomic units (e.g., net present value (NPV) of finfish)" [41]. This illustrates the need to obtain economic data about ecosystem services.

In connection with the above study, it should be concluded that it is possible to include ecosystem services in financial forecasts in the field of spatial planning. The method commonly used to forecast the effects of investments, and thus the effects of introducing a new act of local law, both in Poland and abroad, is the NPV economic indicator method [42]. The factor added to NPV can be a way to protect ecosystems as it represents the legitimacy of leaving ecosystems undeveloped and in a state where they can provide ecosystem services. These studies can also be considered in a broader scope and are applicable not only in Poland but also in planning in other countries.

Author Contributions: Conceptualization, R.B., H.H.-G.; methodology R.B., H.H.-G.; validation, R.B., H.H.-G.; data analysis, H.H.-G., A.H.-N., A.P.; writing-Original draft preparation R.B., H.H.G., A.H.-N., A.P.; writing—Review and editing, R.B., A.H.-N., visualization, H.H.-G., A.H.-N.; supervision, R.B.; All authors have read and agreed to the published version of the manuscript.

Funding: This research received no external funding.

Institutional Review Board Statement: Not applicable.

Informed Consent Statement: Informed consent was obtained from all subjects involved in the study.

Data Availability Statement: The data presented in this study are available on request from the corresponding author. The data are not publicly available due to municipalities policy.

Conflicts of Interest: The authors declare no conflict of interest.

\section{References}

1. Grilli, G.; Jonkisz, J.; Ciolli, M.; Lesinski, J. Mixed Forests and Ecosystem Services: Investigating Stakeholders' Perceptions in a Case Study in the Polish Carpathians. For. Policy Econ. 2016, 66, 11-17. [CrossRef]

2. Zhang, J.; Yin, N.; Wang, S.; Yu, J.; Zhao, W.; Fu, B. A Multiple Importance-Satisfaction Analysis Framework for the Sustainable Management of Protected Areas: Integrating Ecosystem Services and Basic Needs. Ecosyst. Serv. 2020, 46, 101219. [CrossRef]

3. Karimi, A.; Yazdandad, H.; Fagerholm, N. Evaluating Social Perceptions of Ecosystem Services, Biodiversity, and Land Management: Trade-Offs, Synergies and Implications for Landscape Planning and Management. Ecosyst. Serv. 2020, 45, 101188. [CrossRef]

4. Damania, R.; Fredriksson, P.G.; List, J.A. The Multiplier Effect of Globalization. Econ. Lett. 2004, 83, 285-292. [CrossRef]

5. Derlatka, A. Synergia Jako Kryterium Ocenyprojektów Rewitalizacji Śródmieść. Bud. Archit. 2017, 16, 19-28. [CrossRef]

6. Belbin, R.M. Chapter 2-The Apollo syndrome. In Management Teams, 3rd ed.; Belbin, R.M., Ed.; Butterworth-Heinemann: Oxford, UK, 2010; pp. 13-23. ISBN 978-1-85617-807-5.

7. Myers, N.D.; Prilleltensky, I.; Hill, C.R.; Feltz, D.L. Well-being self-efficacy and complier average causal effect estimation: A substantive-methodological synergy. Psychol. Sport Exerc. 2017, 30, 135-144. [CrossRef]

8. Bolund, P.; Hunhammar, S. Ecosystem Services in Urban Areas. Ecol. Econ. 1999, 29, 293-301. [CrossRef]

9. Urban Agenda for the EU. Available online: https:/ /ec.europa.eu/futurium/en/urban-agenda (accessed on 27 January 2021).

10. Feledyn-Szewczyk, B. Bioróżnorodność Jako Wskaźnik Monitorowania Stanu Środowiska. Studia Rap. IUNG PIB 2016, 47, 105-124. [CrossRef]

11. Solon, J.; Roo-Zielinska, E.; Affek, A.; Kowalska, A.; Kruczkowska, B.; Wolski, J.; Degórski, M.; Grabińska, B.; Kołaczkowska, E.; Regulska, E.; et al. Świadczenia Ekosystemowe w Krajobrazie Młodoglacjalnym. In Ocena Potencjału i Wykorzystania [Ecosystem Services in a Postglacial Landscape. Assessment of Potential and Utilisation]; Wydawnictwo Akademickie SEDNO: Warsaw, Poland, 2017; ISBN 978-83-7963-062-2.

12. Document. Available online: https:/ /bip.malopolska.pl/uglapanow,a,197387, uchwala-nr-vii4403-rady-gminy-lapanow-z-dnia4 lipca-2003-r-w-sprawie-uchwaleniamiejscowego-planu-zago.html (accessed on 23 January 2021).

13. Document. Available online: https://www.dobczyce.pl/sites/default/files/upload/uchwala_xviii.110.16_bienkowice_dz.urz_ .pdf (accessed on 20 January 2021).

14. Document. Available online: http://www.gdow.e-mpzp.pl/tekst/XXXVI_249_2017_ror.pdf (accessed on 20 January 2021).

15. Hrehorowicz-Gaber, H. Contemporary Changes, and Development of Spatial Structures in the Carpathians. Conditions and Development Models. Cracow University of Technology: Cracow, Poland, 2019. 
16. Coutts, C.; Hahn, M. Green Infrastructure, Ecosystem Services, and Human Health. Int. J. Environ. Res. Public Health 2015, 12, 9768-9798. [CrossRef]

17. Blazy, R. Living Environment Quality Determinants, Including PM2.5 and PM10 Dust Pollution in the Context of Spatial Issues-The Case of Radzionków. Buildings 2020, 10, 58. [CrossRef]

18. Haashemi, S.; Weng, Q.; Darvishi, A.; Alavipanah, S.K. Seasonal Variations of the Surface Urban Heat Island in a Semi-Arid City. Remote Sens. 2016, 8, 352. [CrossRef]

19. Fromm, O. Ecological Structure and Functions of Biodiversity as Elements of Its Total Economic Value. Environ. Resour. Econ. 2000, 16, 303-328. [CrossRef]

20. Riechers, M.; Strack, M.; Barkmann, J.; Tscharntke, T. Cultural Ecosystem Services Provided by Urban Green Change along an Urban-Periurban Gradient. Sustainability 2019, 11, 645. [CrossRef]

21. Solon, J. Koncepcja "Ecosystem Services" i jej zastosowania w badaniach ekologiczno-krajobrazowych. Probl. Ekol. Krajobrazu 2008, 21, 28-30.

22. McCauley, D.J. Selling out on nature. Nature 2006, 443, 27-28. [CrossRef] [PubMed]

23. Costanza, R.; de Groot, R.; Sutton, P.; van der Ploeg, S.; Anderson, S.J.; Kubiszewski, I.; Farber, S.; Turner, R.K. Changes in the global value of ecosystem services. Glob. Environ. Chang. 2014, 26, 152-158. [CrossRef]

24. Kronenberg, J. Betting against Human Ingenuity: The Perils of the Economic Valuation of Nature's Services. BioScience 2015, 65, 1096-1099. [CrossRef]

25. Bjornstad, D.J.; Kahn, J.R. (Eds.) The Contingent Valuation of Environmental Resources; Edward Elgar: Cheltenham, UK, 1996.

26. Kronenberg, J. Ustugi Ekosystemów-Nowe Spojrzenie na Wartość Środowiska Przyrodniczego; Wydawnictwo Uniwersytetu Łódzkiego: Łódź, Poland, 2016; ISBN 978-83-7969-576-8.

27. De Groot, R.S.; Wilson, M.A.; Boumans, R.M.J. A typology for the classification, description and valuation of ecosystem functions, goods and services. Ecol. Econ. 2002, 41,393-408. [CrossRef]

28. Convention on Biological Diversity (CBD). 1992. Available online: https:/ / www.cbd.int/ (accessed on 20 January 2021).

29. The EU Biodiversity Strategy to 2020. Available online: https:/ / ec.europa.eu/environment/nature/biodiversity/strategy_2020 /index_en.html (accessed on 27 January 2021).

30. Dubel, A. Comparative analysis of methods of environmental vaulation. case study of błonia krakowskie. Prace Naukowe Uniw. Ekon. Wroc. 2017, 122-131. [CrossRef]

31. Atkinson, G. Environmental valuation and benefits transfer. In Cost-Benefit Analysis and Incentives in Evaluation. The Structural Funds of the European Union; Florio, M., Ed.; Edward Elgar Publishing: Cheltenham, UK, 2006.

32. Landers, D.H.; Nahlik, A.M. Final Ecosystem Goods and Services Classification System (FEGS-CS)(EPA/600/R-13/ORD-004914); US Environmental Protection Agency, Office of Research and Development: Washington, DC, USA, 2013.

33. Mikołajczyk, P. Mapowanie i Ocenaekosystemów i Ich Usług w Polsce. UNEP GRID—Warszawa, 7 October 2015.

34. Pueyo-Ros, J. The Role of Tourism in the Ecosystem Services Framework. Land 2018, 7, 111. [CrossRef]

35. Dancewicz, A. Pole Opadów Atmosferycznych w Otoczeniu Sztucznych Zbiorników Wodnych Otmuchów i Nysa Przed i Po Ich Powstaniu. Wiad. Inst. Meteorol. Gospod. Wodnej 1993, XVI, 70-85.

36. Hall, D.K.; Frei, A.; DiGirolamo, N.E. On the frequency of lake-effect snowfall in the Catskill Mountains. Phys. Geogr. 2018, 39, 389-405. [CrossRef] [PubMed]

37. Matuszko, D. Próba określenia wpływu zbiornika wodnego na zachmurzenie i usłonecznienie (na przykładzie Zbiornika Dobczyckiego). In Rola Stacji Terenowych w Badaniach Geograficznych; Instytut Geografii i Gospodarki Przestrzennej Uniwersytetu Jagiellońskiego: Kraków, Poland, 2005; pp. 79-91.

38. Available online: https://www.nbp.pl/home.aspx?f=/dzienne/stopy.html (accessed on 5 January 2021).

39. Costanza, R.; d'Arge, R.; De Groot, R.; Farber, S.; Grasso, M.; Hannon, B.; Limburg, K.; Naeem, S.; O'neill, R.V.; Paruelo, J. The Value of the World's Ecosystem Services and Natural Capital. Nature 1997, 387, 253-260. [CrossRef]

40. Knoke, T.; Gosling, E.; Paul, C. Use and Misuse of the Net Present Value in Environmental Studies. Ecol. Econ. 2020, 174, 106664. [CrossRef]

41. Guerry, A.D.; Ruckelshaus, M.H.; Arkema, K.K.; Bernhardt, J.R.; Guannel, G.; Kim, C.-K.; Marsik, M.; Papenfus, M.; Toft, J.E.; Verutes, G.; et al. Modeling benefits from nature: Using ecosystem services to inform coastal and marine spatial planning. Int. J. Biodivers. Sci. Ecosyst. Serv. Manag. 2012, 8, 107-121. [CrossRef]

42. Yemshanov, D.; McCarney, G.R.; Hauer, G.; Luckert, M.M.; Unterschultz, J.; McKenney, D.W. A real options-net present value approach to assessing land use change: A case study of afforestation in Canada. For. Policy Econ. 2015, 50, 327-336. [CrossRef] 